This PDF is a selection from an out-of-print volume from the National Bureau of Economic Research

Volume Title: International Taxation and Multinational Activity

Volume Author/Editor: James R. Hines, Jr.

Volume Publisher: University of Chicago Press

Volume ISBN: 0-226-34173-9

Volume URL: http://www.nber.org/books/hine00-1

Conference Date: November 14-15, 1997

Publication Date: January 2000

Chapter Title: Transaction Type and the Effect of Taxes on the Distribution of Foreign Direct Investment in the United States

Chapter Author: Deborah L. Swenson

Chapter URL: http://www.nber.org/chapters/c10721

Chapter pages in book: (p. 89 - 112) 


\section{Transaction Type and the Effect \\ of Taxes on the Distribution \\ of Foreign Direct Investment in the United States}

Deborah L. Swenson

\subsection{Introduction}

This paper studies how the tax responsiveness of foreign direct investment (FDI) differs across investment types. Most analyses of foreign investment rely on aggregate data such as flow of funds, the volume of new enterprises in the United States, or the operations of foreign subsidiaries in the United States. ${ }^{1}$ While these data provide a comprehensive description of overall investment activities, they are less informative if one wishes to analyze individual firm decisions.

There are at least two reasons that treatment of firm issues is warranted in the analysis of the tax effects on the distribution of foreign investment. To begin, we know that any set of tax rules may lead to different consequences for firms that are in different positions. For example, it is well known that tax changes are likely to have different effects on old and new capital. In the context of this paper, these differences might reveal themselves in different effects for new plants versus mergers and acquisitions. To the extent that firms located in some countries are more likely to perform acquisitions than greenfield investment, apparent country differences in

Deborah L. Swenson is associate professor of economics at the University of California, Davis, and a faculty research fellow of the National Bureau of Economic Research.

The author thanks the Institute for Global Cooperation and Conflict and Institute for Governmental Affairs at UC Davis for research support. Carissa Perez provided outstanding research assistance. All remaining errors are the author's.

1. These are exemplified by U.S. Department of the Treasury flow of funds data, and by annual Bureau of Economic Analysis (BEA) articles in the Survey of Current Business and BEA surveys of foreign investment activities of foreign affiliates in the United States or of U.S. affiliates abroad. 
tax responsiveness will reflect these countries' investment compositions as well as the structure of the tax reform itself. ${ }^{2}$

We might also expect that investors pursuing acquisitions or joint ventures would place a higher value on the nontax attributes of prospective investment choices than would foreign investors involved in greenfield investment. When a foreign firm decides to make a U.S. acquisition and selects an acquisition target, that firm has decided that it is cheaper and faster to acquire the U.S. target's intangible assets than to develop these assets internally. While the firm might prefer to locate in a state that has lower taxes, its choice will be constrained by the location and availability of appropriate targets. As a result, taxes are less likely to change such a firm's decisions, unless the tax costs are extraordinarily large relative to the nontax advantages offered by a particular target. In addition, these taxes may not impose severe costs on the foreign acquirer because the taxes should be capitalized, reducing the ultimate acquisition price of the target firm.

The second reason we might expect different types of investments to respond more or less vigorously to tax differentials is that various investment transactions will be subject to differing degrees of investment persistence. Investment persistence is the tendency of firms to select locations that have already been selected by their predecessors in the industry, and it may be driven by either agglomeration externalities or specific factor endowments. If agglomeration economies are present, new investors benefit from externalities gained from operation within close proximity to other firms in the same industry. In support of these arguments, Head, Ries, and Swenson $(1999,1995)$ demonstrate that Japanese investors prefer to locate in states that have been selected previously by U.S. or other Japanese firms in their respective industries. This analysis finds that the tendency toward agglomeration or investment persistence is more generally observable in the behavior of all foreign investors.

It is also likely that investment persistence derives from the cost structure of multinational activity. In the context of exports, Roberts and Tybout (1995) demonstrate how previous firm decisions can predispose firms toward continuation of prior activity. ${ }^{3}$ Since new investors are not constrained by prior firm decisions, they should be more responsive to tax differentials than are firms that have established earlier operations in the

2. In a similar vein, Auerbach and Hassett (1993) show that a country's response to TRA 1986 depends on compositional issues, such as the fraction of acquisitions in the country's foreign investment. They argue that distinctions that classify investors into residential versus territorial categories are called into question by evidence that the relative importance of manufacturing investment increased for both territorial and residential investors after TRA 1986.

3. See Markusen (1995) for a survey of multinational firms' decision making. Markusen and Venables (1996) provide simulations that illustrate the potency of these effects. 
United States. As a result, I expect that states with higher taxes may, ceteris paribus, attract fewer new investments.

The practical implication of agglomeration economies and other rigidities in investment decisions is that past decisions will affect current foreign investors' responsiveness to taxes. A state that offers few agglomeration benefits to prospective investors may not be attractive even if it offers a lower tax rate. Although I do not focus on investment persistence in this study, I believe it is a phenomenon for which one must control if one is to measure tax effects accurately. To implement controls for investment persistence I introduce variables that describe the industry similarities of states in the eyes of the prospective investor. ${ }^{4}$

This study utilizes individual firm investment transactions data. The information that is especially important to this study is the classification of transaction type-merger/acquisition, plant expansion, new plant, joint venture, or equity increase - as well as information on the industry of investment. The presence of these industry classifications (in conjunction with data from the U.S. Bureau of the Census) allows me to examine the potency of tax effects across investment types.

Other work on the tax responsiveness of inbound investment flows to the United States has yielded mixed results, though the studies that identify the dampening effects of taxes on investment tend to provide more precise tax measures. ${ }^{5}$ I find that transaction type is another dimension that should be considered by researchers in creating more precise measures. High state taxes are associated with inhibited levels of new plant or plant expansion. In contrast, even after one controls for state characteristics and industry-specific agglomeration economies, it appears that the level of foreign merger and acquisition activity is positively correlated with high state taxes. I discover that a portion of the cross-country heterogeneity in tax responsiveness can be attributed to national differences in the composition of investment flows, especially whether investors from a particular country have engaged more in greenfield investments than mergers and acquisitions.

The paper proceeds as follows. Section 4.2 develops a simple model of investment to motivate the importance of taxes and agglomeration mea-

4. Other studies have implemented the investment choice as a sequential decision framework in which the investor chooses a region first, then selects a state from that region in the second stage. This framework lends itself to nested-logit estimation. I choose to condition on investment persistence terms instead, because they allow for greater flexibility in the determination of relevant state choices by industry.

5. Hines (1996b), Bartik (1991), and Wasylenko (1991) provide comprehensive reviews of the evidence. In general, more powerful tax effects are found by studies that look at smaller jurisdictions (such as metropolitan areas), as compared with interstate or international distributions of investment. Greater effects also tend to emerge in studies that tailor the tax terms to the particular industry of investment or to investor characteristics, as in Papke (1991). 
sures, and to provide a background for the later econometric specification. Section 4.3 describes the construction of the data set and provides some details regarding country differences in foreign investment activities. Econometric tests of the investment model are performed in section 4.4, which is followed by concluding comments in section 4.5.

\subsection{Research Design}

\subsubsection{General Framework}

I choose a flexible estimation framework that is based on the assumption that foreign firms have decided to invest in the United States, and that each will select that U.S. state for which its rise in incremental profits is the greatest. This approach can be estimated by conditional logit models developed by McFadden (1974). ${ }^{6}$ Both the firm's activities and the industrial composition of each prospective state affect the firm's decisions regarding current investments. Although we can't observe profits directly, we can use information on firms' actual investment choices to draw inferences about the effects of various state characteristics.

Suppose that, in general, the incremental after-tax profit a firm earns on a current investment placed in state $s$ can be represented as

$$
\Pi_{s}=\pi\left(v_{s}, p\right) *\left(1-\tau_{s}\right) .
$$

The reduced-form profit function represents the additional operating profit the firm will generate if it chooses state $s .^{7}$ The function includes arguments for input costs $v$, and taxes $\tau$, both of which are unique to the recipient states. The effects of state-specific factors or agglomeration economies are captured in the input costs $v$ because these externalities reduce input costs. Two possible agglomeration externalities would include a welldeveloped supplier network or a pool of highly specialized labor. Because the extent of these externalities rises as a state gains a high concentration of firms in a particular industry, one would expect a state's attractiveness to increase as its concentration of relevant firms increases. A difference between investment persistence based on agglomeration economies and investment persistence driven by industry-specific factors is that specific

6. Work on investment that adopts this approach was initially performed by Carlton (1983) and Bartik (1985). Bartik (1991) surveys work in this area.

7. I abstract from the issue of formula apportionment. Because it is difficult to attribute profits precisely to particular states, states instead define taxable income as some share of the firm's national income, with the share imputed through formula apportionment. Typically, the share calculations are based on a weighting scheme that includes the firm's capital, wages, and sales in a state relative to its capital, wages, and sales nationally. See Gordon and Wilson (1986) for a discussion of the implications of formula apportionment, or Klassen and Shackelford (1997) for empirical evidence regarding the effects of formula apportionment on state revenues as related to state tax rates. 
factors may face ultimate congestion, whereas agglomeration externalities may grow indefinitely with industry size. In principle, it might be possible to disentangle investment incentives based on agglomeration economies from investment persistence driven by factor-specific endowments. ${ }^{8}$ However, this would require one to use a sufficiently long time series, and could be tested only if it were possible to assume that industry factor demands were not changed over time by underlying influences such as technical change. For the purposes of this paper, I term the propensity of firms to cluster agglomeration, but I remain agnostic on its source. The primary benefit of controlling for agglomeration effects or investment persistence is that it provides a flexible method for characterizing the states an investor might select, rather than assuming that all states are equally substitutable a priori, or imposing an arbitrary structure for investor substitution among states.

Another element of the firm's profit function is the price of the firm's output $p$. However, I assume that the final goods price is the same regardless of the investment location selected, because there is no reason to believe that the value of a product depends on the state in which it is produced. As a result, though price influences the level of profits, it will not exert any effect on the relative attractiveness of one state compared with the others, and does not need to be included in the econometric specification.

Under this set of conditions, if the gain in operating profits exceeds the fixed cost of investing in the new operations, the firm will place its investment in the state that yields the greatest profits. As long as the component of the profit function that is attributable to agglomeration economies is separable from the component of the profit function attributable to other factors, the profitability of state $s$ to investor $i$ can be represented as

$$
\Gamma_{i s}=\delta_{s}+\beta_{u s} * \ln \left(\text { Est-US }_{i s}\right)+\beta_{f} * \ln \left(\text { Est-For }_{i s}\right)+\gamma \ln \left(1-\tau_{s}\right)+\varepsilon_{s} .
$$

In this formulation, the attractiveness of state $s$ to the representative investor is captured by $\delta_{s}$. The Est-US and Est-For terms capture agglomeration economies by measuring the counts, at the time of $i$ 's investment decision, of U.S. and foreign establishments in state $s$, which are in the same industry as firm $i$.

The probability that state $s$ yields the highest profits to investor $i$ is given by the logit expression

$$
\operatorname{Pr}(i s)=\frac{\exp \left(\Gamma_{i s}\right)}{\sum_{s \in S} \exp \left(\Gamma_{i s}\right)} .
$$

8. One would also need to characterize how firms form their expectations, unless one can assume that current agglomeration economies are a sufficient statistic for the future path. 
I use maximum likelihood techniques, based on these probabilities, to estimate the tax, investment persistence, and state fixed effects.

\subsubsection{Tax Issues}

The reduced-form profit function in equation (1) displays the after-tax profits a foreign firm will earn in the United States before it repatriates its funds to the parent firm for distribution to its owners or shareholders. As a result, the amount of money that the firm has available for ultimate distribution depends, in part, on how the parent firm's home country treats taxes already paid in host-country locations such as the United States.

The notable distinction to consider here is whether the parent firm is taxed by its home taxing authority on a territorial or residential basis. Firms such as those from France or Germany that are taxed on a territorial basis are not taxed on their foreign earnings. As a result, equation (1) provides a fairly accurate view of their net of tax earnings.

In contrast, firms headquartered in residential tax countries are liable for taxes in their home countries for all earnings, both domestic and foreign. At the same time, these firms are usually given a credit for taxes already paid on their foreign earnings. The firm is left with a home tax liability that is based on the residual difference between its assessed home tax bill and any taxes deemed paid on its foreign income. One can not determine a priori whether a firm will pay additional tax to its home taxing authority. However, firms of residential origin are likely to owe home taxes if the rate of home taxation exceeds the amount of taxes paid in the United States and if the foreign firm is in an excess limit position. ${ }^{9}$

The consequence of this tax distinction is that foreign firms of territorial origin should be especially sensitive to state tax differences, since any additional taxes levied will diminish their profits one for one. In contrast, firms of residential origin may not be affected by differences in state taxation if the assessed tax burdens they face at home exceed the amount of taxes they pay in the United States. However, if firms of residential origin are in an excess credit position, then they should respond to interstate tax differentials in a fashion that is similar to that of territorial investors, since their profits are diminished by U.S. state taxes in an equivalent manner. As shown in Hines (1996a), the territorial/residential distinction implies that territorial investors should respond to interstate tax differentials more vigorously than would residential investors.

9. For the late 1980s and early 1990s this would imply that U.K. firms should be more responsive to U.S. taxes than were Japanese firms, as the rate of corporate taxation was lower in Britain than in Japan. 


\subsection{Data}

\subsubsection{Foreign Investment Transactions}

The foreign investments analyzed in this paper are collected from the publication "Foreign Direct Investment in the United States." ${ }^{10}$ The data define foreign investment to be any transaction for which a foreign firm has the direct or indirect ownership of 10 percent or more of the voting securities of an incorporated business enterprise, or an equivalent interest in an unincorporated business. The roster of firms analyzed in this study includes all manufacturing sector foreign investments conducted between 1984 and $1994 .^{11}$

The interesting feature of these data is that they not only record the state of the investment, the nationality of the investor, and the four-digit Standard Industrial Classification (SIC) of the industry in which the investment is placed, but that they also distinguish the type of investment. There are six categories: New Plant, Plant Expansion, Merger and Acquisition, Joint Venture, Equity Increase, and Other. The final category (Other) represents investments that do not fit neatly into one of the previous categories, and/or transactions the designations of which are precluded by a lack of information. The data on transaction type are used to create a set of interaction terms, which are used to test for variation in tax response across transaction type.

Table 4.1 presents an overview of the data. Of the full 3,212-observation sample, the most frequently represented transaction is Mergers and Acquisitions. This is followed by New Plant and, more distantly, by Plant Expansion activities, Other transactions, Joint Ventures, and Equity Increases. The low number of equity increase observations may reflect reporting differences, because it is possible that physical investments are more accurately observed than are financial decisions. Nonetheless, underreporting of this category should not bias the estimation of coefficients, because the conditional logit framework is based on the observation of individual decisions. Though the equity increase variables may be estimated with less precision, the magnitude of their effects will not be biased unless there is some systematic difference between the universe of equity increases and the subset that appears in the data set.

10. The International Trade Administration of the U.S. Department of Commerce is responsible for this data collection. This data collection effort was initiated by Executive Order no. 11,858, dated 7 May 1975, by which the Secretary of Commerce is responsible for "the obtainment, consolidation, and analysis of information on foreign direct investment in the United States."

11. This paper considers the same data source that is the basis of the study by Ondrich and Wasylenko (1993). However, since their work focuses only on the new plants built between 1978 and 1987, they cannot address the tax responsiveness of other investment types. 


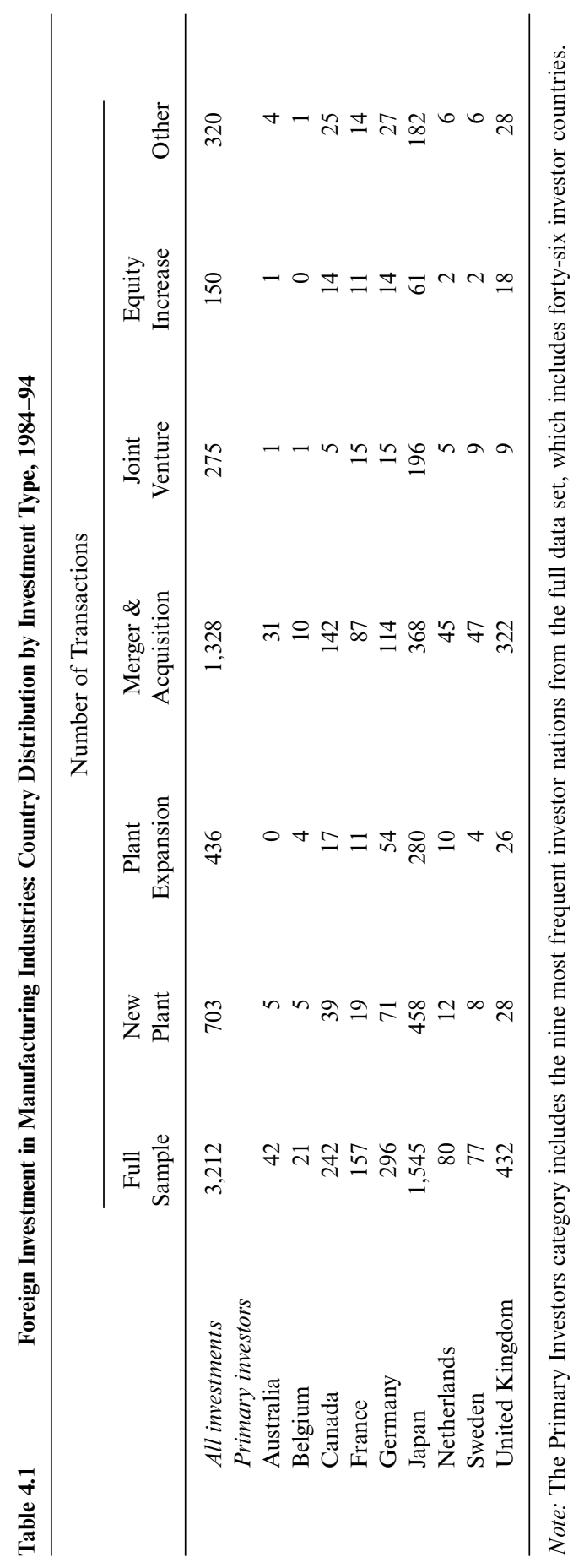


Although forty-six countries are responsible for the transactions included in the data set, many of their investors conducted only a handful of transactions each. Table 4.1 provides a view of the composition of investment types for the most frequent investors in the United States. What is striking is the heterogeneity in investment activities. As has been remarked elsewhere, Japan more than other countries was engaged in new plant, plant expansion, and joint venture activities. Although Japanese investors completed a number of large acquisitions that captured news headlines, they engaged in acquisition activity less frequently than the average country. Germany was the other large investor that was more heavily involved in new plant and plant expansion activity than in acquisitions. In contrast, firms from the United Kingdom, France, and Sweden were most frequently involved with acquisitions. If tax effects differ across transaction types, then cross-country differences in investment composition could cause researchers to attribute cross-country heterogeneity in tax responses incorrectly to country differences, rather than to differences in transaction prevalence. ${ }^{12}$

\subsubsection{Investment Persistence and Agglomeration}

In order to measure investment persistence, or agglomeration, I use establishment counts that are collected from the U.S. Bureau of the Census in Darney $(1992,1996)$. The variable Est-US $S_{s, t}$ provides the count of firms in state $s$ in the same four-digit SIC industry as the prospective investor in year $t$. Unlike the investment data, which are collected on an annual basis, the establishment census is conducted only every five years. The most recent counts were performed in 1982, 1987, and 1992. As a result, the independent variables that describe establishment activity must be attached to recent year counts. ${ }^{13}$ For this study, transactions completed between 1984 and 1986 were attached to the 1982 industry establishment counts; transactions occurring between 1987 and 1991 were attached to the 1987 counts; and the transactions of 1992 to 1994 were attached to the 1992 counts.

In Head, Ries, and Swenson $(1999,1995)$ it is apparent that Japanese firms respond not only to overall establishment counts but also to counts of Japanese establishments. To capture both the foreign element and the overall pattern, I use the 1974-83 rosters of my transactions data to create Est-For ${ }_{i s}$. This variable counts the number of foreign firms located in a

12. I assume that cross-country differences are not driving firms' decisions regarding the type of transaction to perform.

13. It would be possible to create an interpolated series that would allow the variable "Est" to evolve over time. However, the use of an arbitrary assignment scheme would introduce measurement error. Another possibility would be to allow "Est" to grow in the intervening years according to some metric, such as state income. However, this scheme is also problematic, because state income or other measures that could be used to apportion the changes may influence investment on their own. 
Table 4.2 Sample Distribution of Est-US ${ }_{i s}$ and Est-For ${ }_{i s}$

\begin{tabular}{lcc}
\hline & Est-US $_{i s}$ & Est-For $_{i s}$ \\
\hline Range & $0-4034$ & $0-72$ \\
Mean & 26 & 3.4 \\
Median & 4 & 1 \\
25th percentile & 0 & 0 \\
75th Percentile & 20 & 3 \\
\hline
\end{tabular}

U.S. state $s$, in the same two-digit industry as the investor, at the time of the foreign investor's decision. I use two-digit counts for this variable for two reasons. First, unlike the Census data, which includes thousands of firms, the foreign rosters have far fewer observations. If I apportion these observations across the fifty states and into 461 four-digit SIC categories, the data are very thin, and almost every count observation is zero. More importantly, there is reason to believe that foreign firms may be attracted to states based on the foreign concentration of similar two-digit industry firms. These foreign firms may be choosing the states because they have upstream or downstream linkages to these prior investors; or, if the prior investors provide information, as suggested by Casella and Rauch (1997), then informational clarity may cause the firms to choose the attractive states for which there is an established track record.

An interesting aspect of these investment variables is their distribution. As table 4.2 shows, the investment counts are highly skewed: whereas some states have a large number of establishments, states in the 25 th percentile of any particular industry have no establishments whatsoever, domestic or foreign.

\subsubsection{Fiscal Variables}

I measure state taxes by corporate tax rates. These corporate tax rates were collected from publications of the National Association of State Development Agencies $(1986,1991)$ and supplemented by tax charts from the Advisory Commission on Intergovernmental Relations. Across the sample period, state tax rates on corporate income ranged from 0 to 12 percent. In all years of the data analysis, the average state tax rate was between 6 and 7 percent. This provides the false impression that state taxes changed very little. However, while the average state tax rate changed little, the average conceals the fact many changed their tax rates in both the positive and the negative direction.

\subsection{Estimation Results}

The primary goal of my analysis is to determine the tax responsiveness of different types of investment in light of investor-specific factors that 
may predispose investors to choose particular states. I begin with an estimation that considers the importance of investor type, then broaden the analysis to consider cross-country differences in tax responsiveness and how these differences relate to transaction type.

The first column of table 4.3 provides a baseline regression that constrains tax effects to be uniform for all transaction types. The coefficient implies that higher taxes reduce the probability that a particular state will be picked by foreign investors. Because I am analyzing transactions data, this describes the effect of taxes on the frequency of investment, as opposed to investment volumes. The regression also includes state fixed effects and two measures of previous industry activity. Although I do not report the individual state fixed effects, they are highly significant, which implies that certain states have characteristics that cause them to be relatively more attractive to all investors.

I also find that both measures of industry activity, my investment persistence variables, are positive and highly significant. These coefficients imply that investors are attracted to states with a high concentration of other firms in their same four-digit industries, and that their propensities to invest in these states is further enhanced if there is a concentration of similar-industry investors of foreign origin. I interpret this as evidence that agglomeration spillovers, or industry-specific factors, are strong determinants of a firm's location decision. The fact that the concentration of foreign investors provides further information implies that information channels opened by the actions of other foreign investors enhance the attractiveness of a state above and beyond the attractiveness indicated by the mostly domestic distribution of firms.

In the second column of table 4.3 I continue to work with the full sample, but I now allow the tax coefficients to differ for exemption or territorial investors, as opposed to residential or worldwide investors. ${ }^{14}$ These results are presented in the second column of table 4.3. Contrary to the predictions, the results indicate that the probability of a state's selection by territorial investors is not statistically related to interstate tax differences. In contrast, I find that higher taxes reduce the probability that a state will be selected by investors of residential origin. An $F$-test reveals that the difference in the coefficients for territorial versus residential investors is statistically significant. This finding contradicts the prediction that territorial investors would be more likely than residential investors to avoid hightax states. However, this finding may be affected by the choice of dependent variable. I am observing investment location decisions, rather than the volume of investments. Although the territorial investors may not

14. In this analysis the designation "territorial" encompasses the investments of firms from Australia, Canada, France, Germany, and Switzerland, whereas the designation "residential" applies to the investments of Japan and the United Kingdom. 


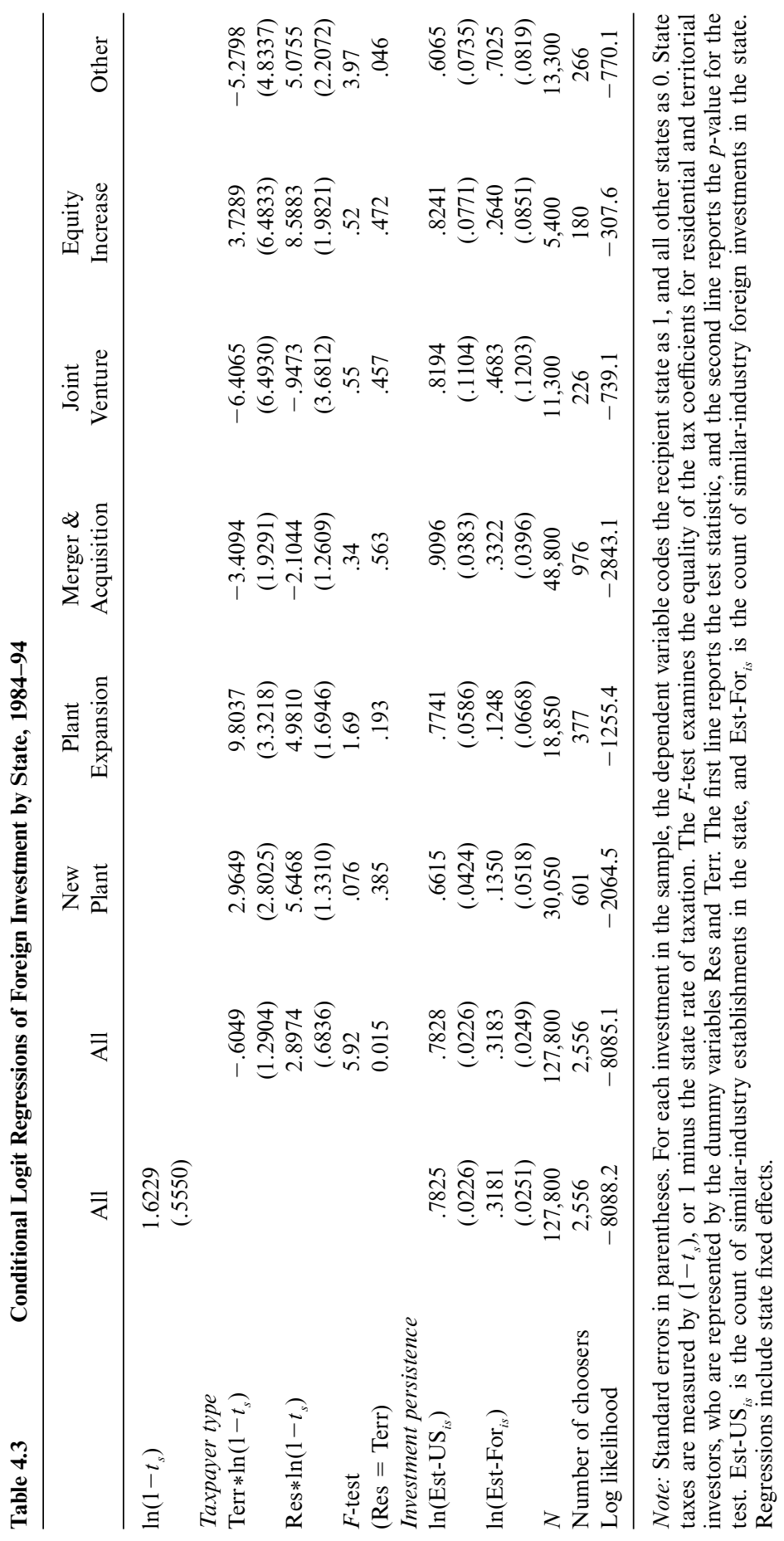


avoid high-tax states altogether, they may place smaller investments in those locations. ${ }^{15}$

I consider the possibility that the distinction between worldwide and territorial investors became more powerful after the implementation of Public Law 99-514, the U.S. Tax Reform Act of 1986 (TRA 1986). Because the full sample covers 1984-94, the early observations predate the implementation of TRA 1986. To see whether the choice of sample period influences my results, I restricted the analysis to investments that occurred after the reform, and repeated the previous regression analysis. However, I do not report these results because the change in time frame does not alter the basic finding.

The last six columns of table 4.3 investigate how the tax responses of residential and territorial investors differ across investment categories. I repeat the previous regression specification, but now restrict the analysis to subsamples of the data that are defined by transaction type. I find that one cannot reject the hypothesis that residential and territorial investors exhibit similar tax responses for new plant, plant expansion, merger, joint venture, and equity increase decisions. All foreign investors performing new plant, plant expansion, or equity increase decisions, regardless of home tax system, appear to be dissuaded from selecting states with higher taxes. In contrast, foreign firms of all origins appear more likely to select higher tax states when they are engaged in mergers and acquisitions or in joint venture activity.

All else being equal, we might expect that tax considerations would inhibit the acquisition of targets located in high-tax states. However, Scholes and Wolfson (1992) demonstrate that there may be a tax clientele effect for foreign investors from worldwide tax countries. If the foreign firms are less adversely affected by high taxes, they may then place a higher value on these targets located in high-tax states. ${ }^{16}$ Collins, Kemsley, and Shackelford (1993) provide evidence that contradicts this notion. They investigated the postacquisition performance of a number of firms purchased by Japanese and U.K. investors after 1986. They find that, at most, only 59 percent of the acquisitions satisfied the conditions that are necessary for the Scholes and Wolfson hypothesis to hold. More important, they find that the most optimistic prediction of tax benefits accruing to these residential purchasers is minuscule when compared with the acquisition prices they paid to purchase their U.S. targets. Barring highly optimistic and unrealistic expectations on the part of these acquirers, the results suggest that nontax

15. Hines (1996a) provides evidence on the volume-versus-frequency question. His work finds that taxes exert a larger effect on shares of plant, property, and equipment value attracted to states than they do on the distribution of foreign affiliates as measured by affiliate counts.

16. If the marginal buyers are U.S. firms, and foreign firms have better tax treatment, then they would be predisposed to the selection of these targets. 
factors dominated tax considerations in these foreign acquisitions. One last surprise in table 4.3 is that the positive association between taxes and acquisitions exists for both territorial and residential investors.

The only disjoint finding in table 4.3 appears in the category "Other." Territorial investors appear to be attracted to higher tax states, whereas residential investors are repelled by higher taxes. The difference in these coefficients is statistically significant. Nonetheless, because the category "Other" contains transactions that were difficult to categorize, I do not place much weight on this finding. The important result of table 4.3 is that foreign residential and territorial investors seem to respond to interstate tax differences in a similar fashion, once one controls for investment type.

In table 4.4 I return to estimates that involve the full sample, but that allow for variation in the tax responsiveness across investment types. In column (2) of table 4.4, I include interaction terms that allow the tax responsiveness of investors to vary across the six types of investment. As I found with the subsamples in table 4.3, foreign investors' new plant, plant expansion, and joint venture activities appear to be repelled by states with higher taxes. At the same time, the probability that a foreign investor will perform an acquisition in a state is positively correlated with tax rates. I also find a positive correlation for the Equity Increase and Other categories, but neither of these effects is statistically significant. Because the Other category is imprecisely defined, I exclude all transactions labelled "other" from my next regression, which is displayed in column (3) of table 4.4. However, the tax coefficients change only modestly, leaving the essential result unchanged.

Finally, in column (4) of table 4.4, I include both the investor-type interaction terms and the transaction-type interaction terms for the four types of transactions that were precisely estimated. I find that the results for the four transaction types are qualitatively similar to the earlier regressions. The only difference is that the statistical significance of the acquisition variable is diminished markedly. At the same time, the residential and territorial variables do not enter the specification in a significant fashion. These results seem to imply that distinguishing investments by transaction type provides more predictive insight when considering tax effects than does the distinction of residential versus exemption investor type.

As a result, I move away from the residential versus territorial distinction, and perform estimations in table 4.5 that allows the tax responsiveness of investment to differ freely across countries. In columns (1) and (2), I consider the full sample first, then a subsample of frequent investors. Column (2) indicates, for example, that only three countries demonstrated a tax responsiveness that was significantly different from zero. Japanese and Belgian investors appear to have avoided high-tax states, whereas the probability of investment for U.K. investors was positively correlated with tax rates. As before, the regressions include fixed effects, and investment 


\begin{tabular}{|c|c|c|c|c|}
\hline & (1) & (2) & (3) & (4) \\
\hline \multicolumn{5}{|l|}{ Taxpayer type } \\
\hline Terr $* \ln \left(1-t_{s}\right)$ & $\begin{array}{l}-.7652 \\
(1.2958)\end{array}$ & & & $\begin{array}{c}-3.0451 \\
(2.0145)\end{array}$ \\
\hline $\operatorname{Res} * \ln \left(1-t_{s}\right)$ & $\begin{array}{l}2.7485 \\
(.6896)\end{array}$ & & & $\begin{array}{c}1.1780 \\
(1.6851)\end{array}$ \\
\hline \multicolumn{5}{|l|}{ Transaction type } \\
\hline $\mathrm{NP} * \ln \left(1-t_{s}\right)$ & & $\begin{array}{c}6.5130 \\
(1.1716)\end{array}$ & $\begin{array}{c}6.2555 \\
(1.1751)\end{array}$ & $\begin{array}{l}8.0356 \\
(2.0110)\end{array}$ \\
\hline $\mathrm{PE} * \ln \left(1-t_{s}\right)$ & & $\begin{array}{c}6.9670 \\
(1.4732)\end{array}$ & $\begin{array}{c}6.7249 \\
(1.4777)\end{array}$ & $\begin{array}{c}8.5039 \\
(2.2016)\end{array}$ \\
\hline $\mathrm{MA} * \ln \left(1-t_{s}\right)$ & & $\begin{array}{r}-3.9668 \\
(1.0611)\end{array}$ & $\begin{array}{r}-4.3677 \\
(1.0655)\end{array}$ & $\begin{array}{r}-2.2443 \\
(1.9392)\end{array}$ \\
\hline $\mathrm{JV} * \ln \left(1-t_{s}\right)$ & & $\begin{array}{c}8.2263 \\
(1.8612)\end{array}$ & $\begin{array}{c}7.9892 \\
(1.8666)\end{array}$ & $\begin{array}{c}9.5683 \\
(2.4855)\end{array}$ \\
\hline $\mathrm{EI} * \ln \left(1-t_{s}\right)$ & & $\begin{array}{c}-4.4710 \\
(3.1641)\end{array}$ & $\begin{array}{c}-4.8322 \\
(3.1725)\end{array}$ & \\
\hline $\mathrm{OT} * \ln \left(1-t_{s}\right)$ & & $\begin{array}{c}-0.5347 \\
(1.9384)\end{array}$ & & \\
\hline \multicolumn{5}{|l|}{ Investment persistence } \\
\hline $\ln \left(\right.$ Est-US $\left._{i s}\right)$ & $\begin{array}{c}.7733 \\
(.0251)\end{array}$ & $\begin{array}{l}.7689 \\
(.0251)\end{array}$ & $\begin{array}{l}.7849 \\
(.0263)\end{array}$ & $\begin{array}{l}.7692 \\
(.0251)\end{array}$ \\
\hline $\ln \left(\right.$ Est-For $\left._{i s}\right)$ & $\begin{array}{c}.3074 \\
(.0281)\end{array}$ & $\begin{array}{l}.2991 \\
(.0280)\end{array}$ & $\begin{array}{l}.2537 \\
(.0295)\end{array}$ & $\begin{array}{l}.2988 \\
(.0280)\end{array}$ \\
\hline$N$ & 127,800 & 127,800 & 114,500 & 127,800 \\
\hline Number of choosers & 2,556 & 2,556 & 2,290 & 2,556 \\
\hline Log likelihood & -8085.1 & -8049.3 & -7264.13 & -8049.1 \\
\hline
\end{tabular}

Note: Standard errors in parentheses. For each investment in the sample, the dependent variable codes the recipient state as 1 , and all other states as 0 . State taxes are measured by $\left(1-t_{s}\right)$, or 1 minus the state rate of taxation. Res and Terr are dummy variables that represent residential and territorial investors. The tax variable is interacted with the following transaction types: NP $=$ New Plant, $\mathrm{PE}=$ Plant Expansion, $\mathrm{MA}=$ Merger and Acquisition, $\mathrm{JV}=$ Joint Venture, EI $=$ Equity Increase, and OT = Other. Est-US ${ }_{i s}$ is the count of similar-industry establishments in the state, and Est-For ${ }_{i s}$ is the count of similar-industry foreign investments in the state. Specification includes unreported state fixed effects.

count variables that measure the propensity towards investment persistence. These variables continue to display high significance, with the investment persistence variables implying that the interstate distribution of foreign investment is highly correlated with the domestic and foreign distribution of economic activity in the same industry.

In the specifications for columns (3) and (4), I augment the specification from columns (1) and (2) with tax interaction terms based on investment type. Again, I choose to include only those terms that were significant before: new plant, plant expansion, and merger and acquisition. Column (4) is the analogue of column (2). I find that the positive correlation I found earlier for the United Kingdom disappears when the investment-type interaction terms are added. At the same time, the magnitude and signifi- 


\begin{tabular}{|c|c|c|c|c|}
\hline & (1) & (2) & (3) & (4) \\
\hline $\ln \left(1-t_{s}\right)$ & $\begin{array}{c}-1.8341 \\
(1.7687)\end{array}$ & & $\begin{array}{l}-.8701 \\
(2.0310)\end{array}$ & \\
\hline \multicolumn{5}{|l|}{ Country effects } \\
\hline $\mathrm{UK} * \ln \left(1-t_{s}\right)$ & $\begin{array}{c}-1.3933 \\
(2.3417)\end{array}$ & $\begin{array}{c}-3.3725 \\
(1.5622)\end{array}$ & $\begin{array}{c}.6118 \\
(2.3766)\end{array}$ & $\begin{array}{l}-.0891 \\
(2.0015)\end{array}$ \\
\hline $\mathrm{JA} * \ln \left(1-t_{s}\right)$ & $\begin{array}{c}6.2367 \\
(1.9088)\end{array}$ & $\begin{array}{c}4.3053 \\
(.7570)\end{array}$ & $\begin{array}{c}3.8987 \\
(1.9466)\end{array}$ & $\begin{array}{c}3.2737 \\
(1.2308)\end{array}$ \\
\hline $\mathrm{FR} * \ln \left(1-t_{s}\right)$ & $\begin{array}{c}-1.5500 \\
(3.0943)\end{array}$ & $\begin{array}{r}-3.5118 \\
(2.5565)\end{array}$ & $\begin{array}{l}-.9453 \\
(3.1165)\end{array}$ & $\begin{array}{r}-1.6497 \\
(2.7691)\end{array}$ \\
\hline $\mathrm{GE} * \ln \left(1-t_{s}\right)$ & $\begin{array}{c}2.1288 \\
(2.4951)\end{array}$ & $\begin{array}{c}.1918 \\
(1.7789)\end{array}$ & $\begin{array}{c}.7150 \\
(2.5244)\end{array}$ & $\begin{array}{c}.1135 \\
(2.0968)\end{array}$ \\
\hline $\mathrm{CA} * \ln \left(1-t_{s}\right)$ & $\begin{array}{c}.7577 \\
(2.6571)\end{array}$ & $\begin{array}{c}-1.2021 \\
(2.004)\end{array}$ & $\begin{array}{c}1.4465 \\
(2.6797)\end{array}$ & $\begin{array}{c}.7658 \\
(2.3059)\end{array}$ \\
\hline $\mathrm{NL} * \ln \left(1-t_{s}\right)$ & $\begin{array}{c}4.4488 \\
(3.6972)\end{array}$ & $\begin{array}{c}2.5011 \\
(3.2613)\end{array}$ & $\begin{array}{c}4.7711 \\
(3.7240)\end{array}$ & $\begin{array}{c}4.1261 \\
(3.4691)\end{array}$ \\
\hline $\mathrm{AS} * \ln \left(1-t_{s}\right)$ & $\begin{array}{c}-3.294 \\
(5.2953)\end{array}$ & $\begin{array}{c}-5.2674 \\
(5.0040)\end{array}$ & $\begin{array}{c}-1.2406 \\
(5.3386)\end{array}$ & $\begin{array}{c}-1.9542 \\
(5.1817)\end{array}$ \\
\hline $\mathrm{BE} * \ln \left(1-t_{s}\right)$ & $\begin{array}{c}24.2665 \\
(6.3180)\end{array}$ & $\begin{array}{c}22.4178 \\
(6.1461)\end{array}$ & $\begin{array}{l}23.8237 \\
(6.4116)\end{array}$ & $\begin{array}{c}23.3171 \\
(6.2794)\end{array}$ \\
\hline $\mathrm{SW} * \ln \left(1-t_{s}\right)$ & $\begin{array}{c}2.3058 \\
(3.8390)\end{array}$ & $\begin{array}{c}.3712 \\
(3.4200)\end{array}$ & $\begin{array}{c}3.5667 \\
(3.8647)\end{array}$ & $\begin{array}{c}2.8777 \\
(3.6038)\end{array}$ \\
\hline \multicolumn{5}{|l|}{ Transaction types } \\
\hline $\mathrm{NP} * \ln \left(1-t_{s}\right)$ & & & $\begin{array}{c}4.9889 \\
(1.5405)\end{array}$ & $\begin{array}{c}4.5010 \\
(1.6092)\end{array}$ \\
\hline $\mathrm{PE} * \ln \left(1-t_{s}\right)$ & & & $\begin{array}{c}5.1002 \\
(1.7578)\end{array}$ & $\begin{array}{c}4.4718 \\
(1.8923)\end{array}$ \\
\hline $\mathrm{MA} * \ln \left(1-t_{s}\right)$ & & & $\begin{array}{c}-5.2352 \\
(1.4767)\end{array}$ & $\begin{array}{c}-5.5501 \\
(1.5633)\end{array}$ \\
\hline \multicolumn{5}{|l|}{ Investment persistence } \\
\hline $\ln \left(\right.$ Est-US $\left._{i s}\right)$ & $\begin{array}{l}.7826 \\
(.0226)\end{array}$ & $\begin{array}{l}.7770 \\
(.0238)\end{array}$ & $\begin{array}{l}.7788 \\
(.0226)\end{array}$ & $\begin{array}{c}.7738 \\
(.0238)\end{array}$ \\
\hline $\ln \left(\right.$ Est-For $\left._{i s}\right)$ & $\begin{array}{l}.3135 \\
(.0251)\end{array}$ & $\begin{array}{l}.3051 \\
(.0265)\end{array}$ & $\begin{array}{l}.3102 \\
(.0251)\end{array}$ & $\begin{array}{c}.3013 \\
(.0264)\end{array}$ \\
\hline$N$ & 160,600 & 144,550 & 160,600 & 144,550 \\
\hline Number of choosers & 3,232 & 2,891 & 3,232 & 2,891 \\
\hline Log likelihood & -10075.9 & -9111.9 & -10045.4 & -9085.9 \\
\hline
\end{tabular}

Note: Standard errors in parentheses. For each investment in the sample, the dependent variable codes the recipient state as 1 , and all other states as 0 . State taxes are measured by $\left(1-t_{s}\right)$, or 1 minus the state rate of taxation. Res and Terr are dummy variables that represent residential and territorial investors. The tax variable is interacted with country- and transaction-type dummies. The dummy variables for nations are $\mathrm{UK}=$ United Kingdom, $\mathrm{JA}=$ Japan, $\mathrm{FR}=$ France, $\mathrm{GE}=$ Germany, $\mathrm{CA}=$ Canada, $\mathrm{NL}=$ Netherlands, $\mathrm{AS}=$ Australia, $\mathrm{BE}=$ Belgium, $\mathrm{SW}=$ Sweden. The dummy variables for transaction type are: $\mathrm{NP}=$ New Plant, $\mathrm{PE}=$ Plant Expansion, and MA $=$ Merger and Acquisition. Specification includes unreported state fixed effects. 
Estimated Transaction Elasticities

$\begin{array}{lr}\text { Tax } & \\ \text { Overall } & -0.108 \\ \text { New plant } & -0.110 \\ \text { Plant expansion } & -0.069 \\ \text { Merger and acquisition } & 0.065 \\ \text { Joint venture } & -0.052 \\ \text { Investment persistence } & \\ \text { U.S. establishments } & 1.196 \\ \text { Foreign establishments } & 0.258\end{array}$

Note: Overall tax elasticity is based on first column coefficient in table 4.3. Disaggregated tax elasticities are based on the fourth column estimates of table 4.4.

cance of the Japanese interaction term fall. Again, these results suggest that many of the perceived differences in the cross-country responsiveness to taxes reflect the composition of these countries' investments, rather than cross-country heterogeneity in the avoidance of high-tax states.

At the same time, the continued strength of the Japan effect is noteworthy. Japan taxes its investors on a residential basis, and is thought to have a higher rate of taxation than that of the United States. As a result, because we would predict that the level of U.S. taxes would affect merely the residual payments Japanese firms make to the Japanese government (but not the overall taxes paid by Japanese firms), we would not expect Japanese firms to be so strongly deterred by taxes.

\subsubsection{Interpretation of Results}

To provide an economic interpretation of my results I present elasticities in table 4.6 that are based on prior regressions. If I consider differential transaction effects, as measured by column (4) of table 4.4, the estimates imply that a 1 percent increase in a state's taxes would cause 0.11 percent fewer new plants to locate within their borders. The state would also attract 0.069 percent fewer plant expansions. On the mergers and acquisitions side, the increase in taxes would be associated with a 0.065 percent increase.

While these responses are precisely estimated, they are all relatively small, which may imply that firms are not likely to be dissuaded strongly from locating in states with higher taxes, because they may have a number of nontax reasons for selecting the states they prefer. At the same time, these firms may decide to minimize the capital and payroll expenses they place in the high-tax states, as these will boost the shares of their incomes that are taxable in the high-tax states.

To put the tax elasticities in perspective, I also calculated elasticities for the agglomeration or investment persistence variables. I learned that a 1 percent increase in the U.S. establishment variable is associated with a rise 
of slightly more than 1 percent in a state's probability of selection. At the same time, a 1 percent rise in the foreign investment persistence variable is correlated with a 0.25 percent rise in a state's probability of selection.

\subsection{Conclusion}

This paper provides evidence on the effect of taxes on foreign investment in the United States between 1984 and 1994. The results suggest that analyses of aggregate data obscure some distinctive effects of taxes on foreign investment. In particular, I demonstrate that states with higher taxes attract fewer new plants or plant expansions; however, foreign acquisitions are not similarly deterred. If one instead analyzes the data delineating investments by investor type (exemption versus foreign tax credit), the results are influenced by the composition of these investors' transaction activities.

Work in international economics, such as Wheeler and Mody (1992) or Brainard (1997), has used fairly simple descriptions of taxes, and has found that the distribution of outbound U.S. investment is, at best, weakly correlated with cross-country tax differences. This analysis suggests that the failure to find significant tax effects may instead reflect problems introduced by aggregation. On a country basis, I find very few significant tax effects. In contrast, the effects that are attributed to transaction type appear to be fairly uniform across investors. As a result, although tax effects may be present and distinct across transaction type, the importance of these tax effects may be lost when one analyzes data aggregated at the country level.

In sum, much of what is interpreted as cross-country heterogeneity in tax response is actually determined by the cross-country heterogeneity in the composition of investment.

\section{References}

Advisory Commission Intergovernmental Relations. Available at http://www. library.unt.edu/gpo/ACIR/Default.html

Auerbach, Alan J., and Kevin Hassett. 1993. Taxation and foreign direct investment in the United States: A reconsideration of the evidence. In Studies in international taxation, ed. Alberto Giovannini, R. Glenn Hubbard, and Joel Slemrod, 119-44. Chicago: University of Chicago Press.

Bartik, Timothy J. 1985. Business location decisions in the United States: Estimates of the effects of unionization, taxes and other characteristics of states. Journal of Business and Economic Statistics 8 (1): 14-22.

1991. Who benefits from state and local economic development policies? Kalamazoo, Mich.: W. E. Upjohn Institute.

Brainard, Lael S. 1997. An empirical assessment of the proximity-concentration 
tradeoff between multinational sales and trade. American Economic Review 87 (4): 520-44.

Carlton, Dennis W. 1983. The location and employment choices of new firms: An econometric model with discrete and continuous endogenous variables. Review of Economics and Statistics 65 (3): 440-49.

Casella, Alessandra, and James E. Rauch. 1997. Anonymous market and group ties in international trade. NBER Working Paper no. 6186. Cambridge, Mass.: National Bureau of Economic Research, September.

Collins, Julie H., Deen Kemsley, and Douglas A. Shackelford. 1993. Taxes and foreign acquisitions in the United States. University of North Carolina, KenanFlagler School of Business, Working Paper.

Coughlin, Cletus C., Joseph V. Terza, and Vachira Arromdee. 1991. State characteristics and the location of foreign direct investment within the United States. Review of Economics and Statistics 68 (4): 675-83.

Darney, Arsen J., ed. 1992. Manufacturing USA: Industry analyses, statistics and leading companies (2nd ed.). Detroit: Gale Research.

Darney, Arsen J., ed. 1996. Manufacturing USA: Industry analyses, statistics and leading companies (5th ed.). Detroit: Gale.

David, Paul A., and Joshua L. Rosenbloom. 1990. Marshallian factor market externalities and the dynamics of industrial location. Journal of Urban Economics 28 (3): 349-70.

Gordon, Roger, and John D. Wilson. 1986. An examination of multijurisdictional corporate income taxation under formula apportionment. Econometrica 54 (6): 1357-73.

Head, C. Keith, John C. Ries, and Deborah L. Swenson. 1999. Attracting foreign manufacturing: Investment promotion and agglomeration economies. Regional Science and Urban Economics 29 (2): 197-218.

. 1995. Agglomeration benefits and location choice: Evidence from Japanese manufacturing investment in the United States. Journal of International Economics 38 (3/4): 223-47.

Hines, James R., Jr. 1996a. Altered states: Taxes and the location of foreign direct investment in America. American Economic Review, 86 (5): 1076-94.

1996b. Tax policy and the activities of multinational corporations. NBER Working Paper no. 5589. Cambridge, Mass.: National Bureau of Economic Research, May.

Klassen, Kenneth J., and Douglas A. Shackelford. 1997. State and provincial corporate tax planning: Income shifting and sales apportionment factor management. University of North Carolina, Chapel Hill, Kenan-Flagler School of Business, Working Paper (June).

Markusen, James R. 1995. The boundaries of multinational enterprises and the theory of international trade. Journal of Economic Perspectives 9 (2): 169-89.

Markusen, James R., and Anthony J. Venables. 1996. The theory of endowment, intra-industry, and multinational trade. NBER Working Paper no. 5529. Cambridge, Mass.: National Bureau of Economic Research, April.

McFadden, Daniel. 1974. Conditional logit analysis of qualitative choice behavior. In Frontiers in econometrics, ed. P. Zaermbka, 104-42. New York: Academic Press.

National Association of State Development Agencies. 1986. Directory of incentives for business investment and development in the United States: A state-by-state guide (new and rev. 2nd ed.). Washington, D.C.: Urban Institute Press.

National Association of State Development Agencies. 1991. Directory of incentives for business investment and development in the United States: A state-by-state guide (3rd ed.). Washington, D.C.: Urban Institute Press. 
Ondrich, Jan, and Michael Wasylenko. 1993. Foreign direct investment in the United States: Issues, magnitudes, and the location choice of new manufacturing plants. Kalamazoo, Mich.: W. E. Upjohn Institute.

Papke, Leslie E. 1991. Interstate business tax differentials and new firm location. Journal of Public Economics 45 (1): 47-68.

Roberts, Mark, and James Tybout. 1995. An empirical model of sunk costs and the decision to export. World Bank Policy Research Working Paper no. 1436. Washington, D.C.: World Bank.

Scholes, Myron S., and Mark A. Wolfson. 1992. Taxes and business strategy: A planning approach. Englewood Cliffs, N.J.: Prentice Hall.

Swenson, Deborah L. 1994. The impact of U.S. tax reform on foreign direct investment in the United States. Journal of Public Economics 54 (2): 243-66.

Wasylenko, Michael. 1991. Empirical evidence on interregional business location decisions and the role of fiscal incentives in economic development. In Industry location and public policy, ed. Henry W. Herzon Jr. and Alan M. Schottmann, 13-30. Knoxville, Tenn.: University of Tennessee Press.

Wheeler, David, and Ashoka Mody. 1992. International investment location decisions: The case of U.S. firms. Journal of International Economics 33:57-76.

\section{Comment William C. Randolph}

There has been substantial interest among economists in behavior underlying the growth of inbound U.S. FDI since the early 1980s. Given the major changes in U.S. federal tax laws during the early and middle 1980s, especially the Tax Reform Act of 1986, a number of researchers have asked how those tax changes influenced inbound investment.

Most of the researchers have used aggregate time series data. Such studies suggest that the tax changes played a significant role in determining the levels of inbound FDI. For example, studies by Scholes and Wolfson (1992) and Swenson (1994) focused on the importance of tax clientele effects whereby multinational based in countries that exempt active foreign source income from tax (territorial systems) should value U.S. investments differently than multinationals based in countries that tax all foreign source income but allow a foreign tax credit (worldwide systems).

Of course, such time series studies have well-known potential limitations. It is often very difficult to identify tax effects separately from the effects of other intertemporal changes - for example, in relative factor input prices, exchange rates, expected rates of return, and so forth. There is always a nagging possibility that the estimated time series effect of tax changes is a spurious indicator of time trends in other important omitted variables.

William C. Randolph is an economist and director of international taxation in the Office of Tax Analysis of the U.S. Department of the Treasury.

The views expressed in this comment are those of the author and do not necessarily represent the views of the U.S. Department of the Treasury. 
Another related line of empirical research has focused on cross-sectional interstate variation of inbound FDI and its relation to interstate variation of tax rates. A notable recent example is the study by Hines (1996). In this line of research, the main econometric challenge is to identify the effects of interstate variation of taxes separately from the effects of interstate variation of public services, factor prices, transportation costs, and the like. Hines (1996) identifies the tax effects separately from those other factors by recognizing that interstate variation in tax rates should influence the location of U.S. inbound FDI by multinationals based in countries with territorial systems by more than the location of investment by multinationals based in countries with worldwide tax systems.

Auerbach and Hassett (1993) have demonstrated cause for concern about studies of inbound FDI because the empirical studies group modes of investment together, without regard to whether the "investment" takes the form of, for example, the acquisition of an existing business or the establishment of a new enterprise. They show that, theoretically, taxes can have different effects on investment, depending on the mode of investment. If so, results of aggregate studies that group the investment modes together would be meaningful only under special conditions.

In this new paper, Deborah Swenson studies the determinants of inbound foreign direct investment by examining microdata on inbound transactions. The data and her model have important features that allow her to pull together different possible information sources to identify the effect of taxes, and to distinguish among the effects of taxes on different modes of investment. The data provide a richness of information on variation in the choice of investment mode and tax rates over time (1984-94), on variation across the states, and on variation in the tax treatment of foreign source income by the countries where the foreign multinationals are based.

This is an area of empirical research in which there has been considerable interest. It has attracted some first-rate analysis by first-rate researchers, all of whom have made use of relatively scant data. It is therefore admirable that Swenson has been able to provide new insight based on data that have gone previously untapped for this purpose.

Swenson uses a logit model to characterize the choice, by a foreignbased multinational corporation, of a U.S. state in which to locate an investment transaction (the basic unit of observation in her data). Because the data span eleven years, they can be thought of as a time series of repeated cross sections. Because state tax rates varied over the time period, by different amounts in different states, she is able to study the effect of taxes while implicitly controlling for all fixed state differences that would potentially affect inbound investment in the same fashion in all years. She also includes measures to capture the possible effects of agglomeration economies on the location of investment. 
To study whether it is important to distinguish among investment modes, the author first estimates the parameters of a pooled regression. She then estimates separate regressions for investments in new plants, plant expansion, mergers and acquisitions, joint ventures, equity increases, and other modes. From the pooled regression, she finds that higher taxes appear to discourage inbound investment transactions by multinationals based in countries with worldwide tax systems. However, taxes do not appear to influence the investment decisions by multinationals based in countries with territorial tax systems. This pair of results, as discussed by the author, is contrary to the economic prediction that local taxes should actually have a larger effect on investment location decisions by multinationals based in territorial countries.

A partial resolution of this unexpected result is apparently provided by the results of separate regressions for different modes of investment. For the separate regressions, tax effects have the predicted signs, overall, for investments in new plants, plant expansion, and equity increases, although only the plant expansion regression estimates are consistent with the prediction that taxes should have a larger effect for multinationals based in territorial countries. State taxes do not appear to have any effect on the likelihood that a multinational enters into a joint venture. For mergers and acquisitions, however, increased state tax rates appear to increase the likelihood that an investment transaction occurs, regardless of the type of home-country tax system. Based on these results for separate investment types, it is reasonable to conclude that the estimation results for the regression are not meaningful when investment types are pooled.

Although this aggregation result is well motivated because, in theory, taxes should affect the cost of capital differently for different modes of investment and differentially situated investors, as shown, for example, by Auerbach and Hassett (1993), the results for the individual regressions are still too peculiar to provide convincing evidence that the differences in the estimated tax effects are really driven by differences in changes in the cost of capital. The central theoretical prediction - that is, that taxes should have a larger effect on investment location decisions by multinationals based in territorial countries - is consistent with the separate regression results for plant expansions only. For investments in the form of new plants and equity increases, taxes actually have the larger effect on multinationals from countries with worldwide systems. For investments in the form of mergers and acquisitions, the tax effect even has the wrong sign. It is possible that the sign reversal results from the type of clientele effect examined by Scholes and Wolfson (1992) and Swenson (1994), but that effect would cause taxes to be positively correlated with acquisitions only when the foreign multinational is based in a country with a worldwide system. In these estimation results, however, not only is the sign the same for both 
groups of multinationals, but it is larger for multinationals based in territorial countries.

These unexpected estimation results may be explained by a data limitation. As discussed by the author, the data on investment transactions are only qualitative. They don't measure the sizes of investments. It might be true that the number of inbound acquisitions is negatively correlated with the total value of acquisitions in a state, although it is hard to imagine why this would be true.

A more likely source of the unexpected results is the lack of control in the regressions for time series aspects of the data. I'm not familiar with the time pattern of inbound investment transaction counts, but inbound FDI in the United States was highly time trended and apparently highly nonstationary during parts of the time period covered by the data examined by Swenson. Moreover, such time patterns differed by type of investment transaction and by location of the home countries of foreign-based multinationals. It is likely that the same patterns were also reflected in transaction counts.

In Swenson's regressions, the tax effects are identified mainly by the fact that state tax rates change over time in different ways in different states. In fact, the tax rate is the only right-hand side variable that changes independently over time. The tax rate coefficients could thus be biased by the omission from the regressions of any time varying factor, such as economic growth, that influenced inbound FDI location decisions. Further, there is no reason to expect this omitted time series bias to be the same for all investment modes, which might explain why only some of the estimation results are anomalous.

Because this study is focused mainly on the effect of taxes, as a solution it may be sufficient to simply control for possible omitted time series by including time trends, measures of growth at the state level, or time dummy variables. Although time dummy variables could not be included for each state, they could be included at either the national level or at a regional level to control for regional differences in time patterns of investment activity.

Swenson's analysis in this paper is a useful contribution to our understanding of investment location decisions. It represents a first step taken with new data and provides important potential for future research. Because the data provide alternative sources of identification for tax effects, they can be used to examine the validity and importance of identifying assumptions made in previous research on inbound FDI. Further, if taxes have different effects on different types of investment transactions, it is also reasonable to expect that taxes should influence the choice of transaction type, a choice that Swenson's paper treats as being exogenous.

I've enjoyed reading and thinking about this paper. I've learned a lot and look forward to future installments. 


\section{References}

Auerbach, Alan J., and Kevin Hassett. 1993. Taxation and foreign direct investment in the United States: A reconsideration of the evidence. In Studies in international taxation, ed. Alberto Giovannini, R. Glenn Hubbard, and Joel Slemrod, 119-44. Chicago: University of Chicago Press.

Hines, James R., Jr. 1996. Altered states: Taxes and the location of foreign direct investment in America. American Economic Review 86 (5): 1076-94.

Scholes, Myron S., and Mark A. Wolfson. 1992. Taxes and business strategy: A planning approach. Englewood Cliffs, NJ: Prentice Hall.

Swenson, Deborah L. 1994. The impact of U.S. tax reform on foreign direct investment in the United States. Journal of Public Economics 54 (2): 243-66. 